\title{
ELECTRUM-G, A Tangible Coin Actualization Schema: Patents for Casting, Forensics and Trade Options
}

\author{
Efi Tsiatsiou \\ Management Science and Technology Faculty (MBA thesis) \\ University of Western Macedonia, 50100 Kozani, Greece
}

Athanasios Zisopoulos

Management Science and Technology Faculty

University of Western Macedonia, 50100 Kozani, Greece

E-mail: zisopoulos.athanasios.dim@gmail.com

Konstantinos Spinthiropoulos

Management Science and Technology Faculty

University of Western Macedonia, 50100 Kozani, Greece

Panagiotis Georganakis

Management Science and Technology Faculty

University of Western Macedonia, 50100 Kozani, Greece

Received: December 23, 2019 Accepted: January 8, 2020 Published: January 30, 2020

doi:10.5296/ber.v10i1.16094ＵRL: https://doi.org/10.5296/ber.v10i1.16094

\begin{abstract}
Our interdisciplinary research concluded with a new member of the ancient Electrum family of golden coins: the ELECTRUM-G coin. It is golden representing an actual value with metal abnormalities to give a universal traceable RID and a modern engravement and other forgery fighting attributes and associated electronics. Other ELECTRUM-G characteristics are ; A tangible item with the form of a coin or sphere; there is a coin engravement with a QR code pointing the Electrum Ecosystem (www.electrum.gr). Four different patents are prepared for
\end{abstract}


the project needs: a unique QR code stamping; a RID code casting; a two-layer gold foundry with RID intermediate layer; and a professional electronics simple spectrometer to read and report the RID code. Two Electrum narrative examples are given for ELECTRUM-G use and forensics, a nouvelle with the happy Electrum traveler and the lyrics of a song defining the "thin line between love and hate". Finally, as inspired scientists we reverse the ELECTRUM Universe with an old story of "Stop RFID" and the beast $(665+1)$ endangerment. Our research and product headlines faced also two contradictory intra-co-operating design aspects: the personal interest of the Electrum-G coin owner and the Public interest of civil and national security.

Keywords: Golden coin, Metallurgy, Casting, Insurance, Internet of Things, Financial intelligence, Spectroscopy, Money laundering

\section{Introduction and History}

Our research for a new golden coin concerns an interdisciplinary sciences approach like any real-life product or service. We investigated various old and new developments in Science and Engineering like:

- Monetary Science to avoid Bitcoin nonsense monetary applications

- Financial Intelligence to harness the wild horse of speculative gold and black money.

- Metal tracking at the lowest possible grain.

- Metallurgy and Casting Engineering to find new ways of molding and stamping.

- Professional Electronics to tailor a new device at the spectrometer range of gold testers.

In our modern times forgery of gold and golden coins raised to enormous heights. The rise of Bitcoin "revolution" has changed the but there are problems (Antoniadis, 2018; Baur, 2018; Vasilios, 2018; Vasilios, 2018). Monetary theory proved two basic money attributes: the nominal and the real value of money. Unfortunately, nominal value dominated the monetary system theory and practice (Eckel, 2011; Carlstrom, 2007). All these crypto-coins (Catalini, 2018; Venegas, 2017) and CBDC (Fung, 2016; Kumhof, 2018; Bordo, 2017) have minimal to zero real value. The golden British Pound served the international community real value stabilization for over two centuries. However, it is about time to design a new coin with characteristics like:

- Coin material must be gold or silver to represent an actual value.

- Internal coin various metal abnormalities to give a universal traceable ID.

- A modern engravement is necessary for marketing and acceptance.

- Other forgery fighting attributes and associated electronics.

In order to proceed with monetary and laboratory metallurgy research we needed a decent name. We evaluated history for our naming conventions and purification evaluation. First, we chose the Electron name as the cornerstone of our modern civilization, electricity.

\subsection{ELECTRON}

Coinage heritage of Classic times has three generations of coin families. The oldest family is 
known under the name of Electrum. Amber is known to mineralogists as succinite (lat.Succinum) or "gum-stone". The Greek name for amber was elektron, and was connected to the Sun god, one of whose titles was the "Elector" or the "Awakener". It is also associated with the word "electricity", because amber becomes electrically charged when rubbed with a cloth and can attract small particles. The word electrum is a Latinized form of the Greek name elektron, a metallic substance consisting of gold alloyed with silver (SINGER, 2008; Heathcote, 1967; Wallace, 1989). In the byzantine times electrum coin issued by Emperor Alexius I Comnenus (Tucker, 2008; Grierson, 1973).

Even in our times Electrum coin is investigated from the metallurgy and numismatics point of view. Three electrum of the king Alyattes type were systematically analyzed, first by nondestructive physical methods, then destructively by chemical analysis, metallurgical testing and the use of the electron microprobe and the scanning microscope (Pászthory, 1980; Howgego, 2002; Healy, 1980). We here and today we propose the modern Electrum version for the Third Greek Democracy (Lyrintzis, 1996).

\subsection{EURECA Gold Testing in Cecily}

The ELECTRUM coin would be useless without an associated counter fighting device. To conclude our history trip, we analyzed Sicily Italy modern school textbook for the Eureka famous phrase, introducing the first gold analyzer 2500 years ago. We remembered Archimedes initial definition of "the Law of Buoyancy" at "EUREKA" moment. Archimedes found the Law of Buoyancy at that moment and proved the theft of the goldsmith (Stein, 1999; Kolata, 2003; Hidetaka, 2010). For our times it seems archaic history with all these gadgets around us. For sure gold testing machines were, and always will be, one step behind the gold coin counterfeiting criminals.

\subsection{ELECTRUM Naming Confusion}

The Electrum name has been in two other similar developments: Electrum software and Electrum wallet. They both have a place in the worldwide Ancient Greek language heritage schema but they do represent misuse and misunderstanding of the history.

A similar development is the "Electrum wallet", an advanced bitcoin holder. It is probably the most secure software wallet. The most advanced feature was the absolute "cold storage", with storage temperature very dissimilar from a coin casting procedure (Jokić, 2019; Langschaedel, 2015). Electronic fraud with "Electrum wallet" and Bitcoin were the reason to revert to a modern gold coin (Biryukov, 2019; Bui, 2019; Voleth, 2019). Of course, archaic electrum was a gold coin and this wallet falsifies Greek History.

Encyclopedia Britannica (Macfarquhar, 2016) refers: "ELECTRUM, ELECTRON (Gr.

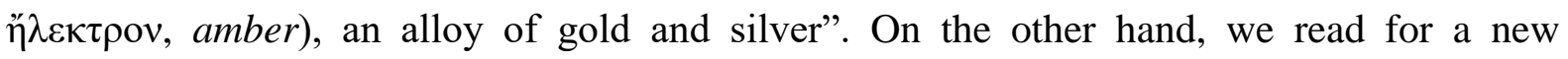
software package :"Electrum is an extension to the Alloy Analyzer providing an analyzer for Electrum models, a temporal extension to the Alloy modeling language (Julien, 2018). Alloy is a simple structural modeling language." Of course, this electrum is a metaphor not a real alloy. To clarify our product, we added a name and the real alloy is our product "ELECTRUM-G". 


\section{The ELECTRUM ECO SYSTEM Golden Coin Definition}

The Electrum started as an academic exercise to reduce crypto coin acceptance of the misguided investors and technology freaks. It shifted as a metallurgy lab to cast and purify gold coins. Then the necessity of a professional low-cost device raised to introduce the coin to our digital world. All design stages are under FIU guidelines for forgery. (FIU) ELECTRUM primarily design characteristics include:

- A tangible valuable item with the form of a coin or sphere.

- The coin (or sphere) is made of pure gold with market accepted impurities.

- The coin value range will be selected at the range of 200-1000 Euros.

- The coin engravement is a QR code pointing the Electrum Ecosystem.

- The ELECTRUM ecosystem at www.ELECTRUM.gr

- The dual layer gold casting and foundry procedure

- A RID Readable Identification label schema inside the coin.

All the above parts have been investigated and there are mature in their final operational form. The brand name it will be ELECTRUM coin but the legal from could be different across various legal systems around the globe. For example, to bypass money issuance prohibition various naming and actualization conventions could be used:

- Electrum-G item.

- Electrum tangible golden jewelry;

- Electrum SKR (Safe Keeping Registry).

- Electrum certified gold swap system.

- Electrum insurance options.

Always we keep in mind that since the system is based on pure gold everlasting money value the most important is the possession of the coin. All other arrangements, facilities and legalities are following primarily for marketing and promotion.

\section{ELECTRUM-G Casting and Foundry}

The coin uses pure gold metal and various acceptable We evaluated different solutions for coin casting and foundry. In business solutions are synonymous with patents giving the necessary preferential status for a long-time profitable operation. The actual inventions cannot reveal fully here primarily because

- The non-economic inventive engineering nature of these developments.

- Invention patents keep secrecy and they are addressed only to their physical judge of OBI (Greece), EPO (Europe Patent Office) and PCT (Patent Cooperation Treaty)

- They need heavy laboratory testing prior their finalization to fulfill patent application restriction along with commercial success. Patent is not an academic exercise.

- Most of the features will be used for large coins where high value makes the feature feasible. 


\section{Macrothink}

\subsection{Patent Number 1, Unique QR Code Stamping}

Every coin has an associated URL at the ecosystem. Example of a coin URL is www.ELECTRUM.gr/123456789. The concept of a unique URL is a straightforward simple coin site. The number 123456789 is indicative of 20 alphanumeric letter passwords. Of course, somebody could accidently approach the coin page but nothing severe could happen, exactly like Bitcoin has open operations but totally encrypted ownership.

At the next step the above URL is converted into QR code with black lines in yellow background. We prepare a on time stamp from this QR code black lines. An industrial stamper machine ( ) presses the black lines to the golden coin and the coin is ready.

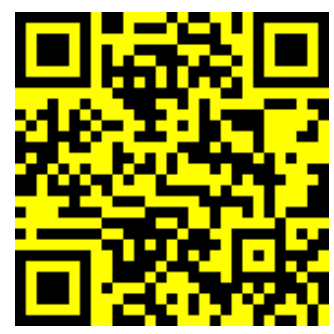

Figure 1. QR code pointing to the coin microsite (www.electrum.gr/password)

As a result, we have a golden coin of a certain money value with a URL-type serial number engraved or stamped on it.

The patent innovation and market goal are to introduce a different one-time stamp for every golden coin. The patent is a generalized URL engraving in real world objects and did not prepared for the ELECTRUM coinage system.

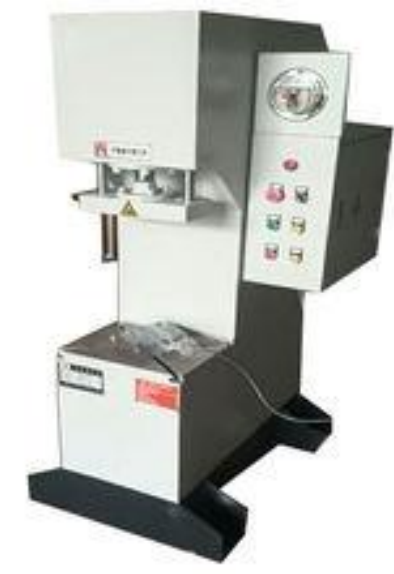

Figure 2. A similar machine (160-ton Stainless steel Hydraulic Press gold Coin Making Machine 


\subsection{Patent Number 2, RID Code Casting}

The gold casting grain contains gold and metals such as copper, silver, nickel, palladium and zinc. All these are alloyed with pure gold to make a gold alloy having various desired properties but mainly to retain and assure pure gold as a monetary item.

The casting and molding machine must distribute rigidly (by molding) in the coin surface various lines or dots of different metals. All these dots and lines will be read by machines like $\mathrm{X}$-ray fluorescence spectroscopy, jewelry spectrometer or others.

\subsection{Patent Number 3, Two-layer GOLD FOUNDRy with RID INTERMEDIATE LAYer}

The patent purpose is to enclose the same like the above metallic RID (Readable Identification) into a rigid golden enclose. The procedure has three stages:

1. Two golden coins each with the half layer thickness is casted and set aside.

2. We put the layer one in the machine and we spray or mold a metallic alloy of metals like copper, silver, nickel, palladium and zinc. This would be the RID code.

3. At the final stage we add the second half of the coin and we homogenize, close hermetically, rigidly sealed etc.

As result we have a golden coin with a RID code embedded. Any attempt to alter the IR code will destroy the coin readability from ELECTRUM systems. The coin retains only the gold value and nothing else. Somebody could say this is the only existing value but we could easily remind him the initial properties of money: durability, portability, divisibility, uniformity, limited supply, and acceptability (Eken, 2017; Whitingg, 1994). In our time other characteristics are more significant like properly taxed, legally earned and existence of AML compliance (Usman, 2014; Naylor, 2003; Sharman, 2008)

The technology to achieve this functionality do not exist today. The procedure could be described as inside the coin rigidly embedded custom RFID. Actual Casting and foundry will not be patented to PCT in order to eliminate forgery. If the coin is melted to acquire the precious metals then the coin serial number is destroyed.

\section{The Commercial Counter Fighting Analyzer}

After such an effort the coin is distributed to the market. In the beginning, only the gold value matters nothing else. But Electrum coin is designed to survive in a complex and competitive market. To exploit full coin capabilities a custom RID reader is needed.

As a first step we evaluated a number of market machines that could facilitate coin recognition and similar technology. They all based on spectrum analyzer theory

A simple machine at a price range of 100 Euro is Dahometer a Digital Ultrasonic Tungsten Gold Tester Machine. It detects gold properties at measuring range: $0.75 \sim 300 \mathrm{~mm}$ with PC connecting and software, display resolution: $0.01 \mathrm{~mm}$ or $0.1 \mathrm{~mm}$ and accuracy: $\pm(0.5 \%$ Thickness + 0.04)mm. 

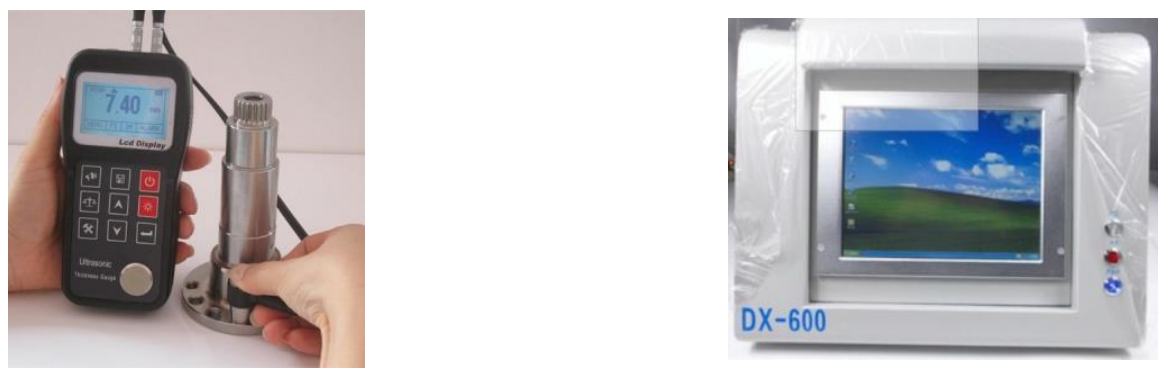

Figure 3. Dahometer Ultrasonic gold tester and DX600 spectrographic

A more expensive with price tag above 1000 Euro is an X-ray Gold Purity Test for Gold Analyzer/Gold Purity Testing Machine/Gold Tester is DX600. It is designed for pawnbroking, jewelry industry, banking industry, mining industry, precious metal recycling, precious metal materials researching laboratory. All these are is very close with Electrum coin customers.

Both systems and a lot of others are capable to read the RID code but they but we need a customized tailored machine. There is no need for another patent application only alteration and calibration of existing market machine. In its simplest form the ELECTRUM reader could use a low energy X-ray machine to scan the golden coin. If the laboratory test is not satisfactory we could use more complex devices but not spectrum analyzers because we only seek for simple patterns in a rigid specific structure. There could more sophisticate dedicated readers

The on-site scanning procedure is simple. The happy Electrum owner wants to exchange a few ELECTRUMs with local money. He delivers to the money changer the golden coins. There the gold-broker feed all the coins one by one into the RID reader. For every coin a RID scan is attempted and send it to the www.electrum.gr site. The site responds and we have a secure verification of all golden coin properties like:

- Coin initial properties like photo and gold and alloy amalgamation.

- Temporospatial information of every verification attempt.

- It does not reveal at any stage RID for forgery protection.

- It proposes a fair local price and a list of certified pawnshops or money changers.

\section{Simple ELECTRUM Use and Forensics}

We cannot locate at the scientific literature a complete money characteristics list therefore we combined various sources. According to various sources money has four, six, seven characteristics (Schwarz, 2011; Renneboog, 2011; Thomas, 2010; Lashitew, 2019; Singh, 2019). We migrated Monetary, Banking and AML worlds and we chose 12 money attributes. All these and the Electrum-Gold compliance is presented below:

1. Durability; it is the most durable material.

2. Portability; it has low portability because of the high atomic weight.

3. Divisibility; it is divided already cannot be divided furthermore.

4. Uniformity; it has higher than all existing standards of uniformity. 
5. limited supply; Gold is a rare metal.

6. Acceptability; Gold and our counter-fighting methods are widely acceptable.

7. Non-counter-fight-ability; falsification impossible

8. properly taxed; under various circumstances taxes paid indication is possible.

9. Discoverable; it is full traceable as long as it remains ELECTRUM-compatible.

10. AML compliance; not our strong point but no other money fulfills this feature.

11. Real value; It has the highest possible real value.

12. Nominal value; nominal and real value are equal.

\subsection{A Happy Electrum Traveler}

The happy Electrum owner traveler is stopped in an airport customs office with a bag of golden Electrum coins. Gold smuggling is a very often Customs case. He delivers to the policemen the golden coins. The authorized clerk feed all the coins one by one into the RID reader. For every coin a RID scan is attempted and send it to the www.electrum.gr site. The site responds and we have a secure verification of all golden coins with a certificate that:

- all these belong to a person with a legal passport number AX543442

- the person carrying the gold has no liabilities or concerns for these specific coins

- All gold is registered and is free of any liabilities and encumbrances.

Very easily a certificate of customs declaration could be issued and the case is closed. It seems nothing but for the traders and businessman traveling around Europe with gold in their luggage's the current procedure is awful. The golden coins are confiscated until a legal prove of value and ownership will be issued. There were cases that seizure duration exceeded ten years. Of course, bribery is a main issue in such cages but the triggering was unregistered gold (George, 2016, 2018).

\subsection{There is a Thin Line between Love and Hate}

This "thin line" is a song from our father times but it is always timely relevant. The story is resembled form a New Testament parable (Luke 12:18) and goes like this.

And he told them a parable,

The commander of the local "Guarda di Financia" started a case against a rich man having a lot of EELECTRUM-G coins. 17and he thought to himself, "What shall I do, for I have nowhere to hide away my registered gold?' 18And he said, 'I will do this: I will melt down all my coins and build unregistered gold plates and I will store along all my grain and my goods. 19And I will say to my soul, "Soul, your gold will be not confiscated for many years; relax, eat, drink, be merry."' 20 But the IRS Commander said to him, 'Fool! This night you will be prosecuted anyway 21 Either for possessing untaxed gold property or unreported stolen Electrum coin property.

The rich man used the registered gold attributes to expand his business and wealth. When the taxation time arrived finally he refused to adapt. He transformed his fully registered coins into pure gold plates belonging to the carrier. At this moment if a thief steals his gold he cannot claim ownership undoubtfully. To end narration with our song, 
- The love is the present happy life and business transaction under the law umbrella.

- The hate is the future hopeless living with policemen, advocates and criminal outside the legitimation roof.

- The thin line is the moment of melting a full feature Electrum coin into an anonymous gold plate.

We expect in the future songs for ELECTRUM to be inspired.

\section{Advanced ELECTRUM Investment Options}

From the local bazaar black market to the international Swiss Banking system we have chosen some implementation options. These applications focus on authenticity feature but all other items are considering.

\section{1 “Electrum-G” Item}

The gold market is a necessity for all civilizations. Profit and property taxes cannot be applied easily in gold items. Therefore, pure gold denotes the definition of tax avoidance and AML choices (Goel, 2015; Teichmann, 2017).

\subsection{Electrum Tangible Golden Jewelry}

In a number of countries god procession casting and all related activities are by law prohibited leading to severe penalties. For these territories we use a similar naming convention to bypass the law. Electrum-gold is a jewelry not a coin.

\subsection{Electrum SKR}

In the top 20 of OECD countries (Berger, 2016) the "Safe Keeping Receipt" valuable interchange use is more common than gold coins. The term Safe Keeping Receipt or SKR, is equal to Safekeeping. The procedure is like this

- an asset owner elects to place that asset in the care of an Agent, a Public notary, a Bank or a Financial Institution

- He receives a receipt as a prove o asset "Safekeeping".

- This receipt is negotiable, send through money wire transfer systems like SWIFT an all type of transaction the investor could imagine.

- The asset owner elect to have such an acknowledgement sent to a third party.

Let assume that an investor has 1000 ELECTRUM-G coins. He delivers the coins to the Bank and gets a receipt. This several pages or even electronic receipt is used interchangeable with money or gold and useful for various transactions like Electrum certified gold swap system and refinery liquidation of the coin gold.

\subsection{Electrum Insurance Options}

Insurance and reinsurance are the cornerstone of worldwide monetary system (Schlesinger, 2013; Mayers, 1983; Clarke, 2016). The Electrum-G is suitable for insurance as it does 
represent real value. However, it has numerous disadvantages:

\section{Reverse the ELECTRUM Universe}

The newly baked coin solves severe security and monetary issues but there is a number of drawbacks in a wider adoption from the investors and consumers.

A few years ago, has been established FoeBuD a Deutche privacy and digital rights non-profit organization. One of their campaign were "Stop RFID" a rather un-successful effort. Their main point relevant to our golden coin effort is that coin embedded inside label remain functional for surveillance practically forever (Spiekermann, 2009; Hennig, 2004).

Another issue we read from the last Bible book (Revelation 13:8) (Campell, 2010):

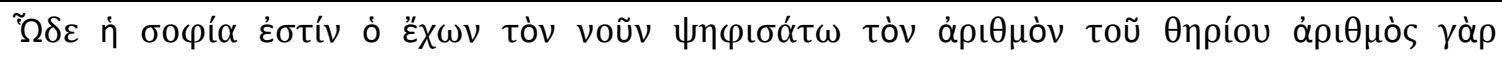

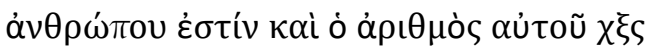

Oere is wistom. Eet him that hath understanding count the number of the beast: for it is the number of a man; and his number is Qsix hundred threescore and six.

In the worldwide literature the number 666 is synonym for the tight embracing of human being by the all type of state authorities. This is very common to our political system from extreme right to extreme people republic political ideology. They all demand politically correct thinking, living and spending. They all promote monetary solutions without real value. ELECTRUM has certified real value, despite the world tearing apart. The "big brother" in this case is the ELECTRUM ECOSYSTEM itself. Every time a verification request is tried, this makes widely visible all temporo-spatial related information of the attempted scan. If or when the power comes to wrong hands the big brother 666 dominates human life. The mark of the beast in our forehead occurred and this life and our next life are terminated at that point of time.

Another idea during this project was to embed into the coin chemical, physical radio active add-ons that could track the ELECTRUM coin gold after casting and recycling. There are a lot of ideas but always with two contradictory interests:

- The golden coin owner primarily concern is not a daily exchange but to keep the gold for the hard times. In any case he does not want to be tracked from Devil electronic systems.

- The state authorities want to retain monetary and gold circulation control due to higher hierarchy needs like terrorism fight and AML.

These two are contradictory but the Electrum owner demands all genuinely assurance and anti-theft tracking to ensure his valuable investment. But these features are created by state authorities and they do exist only in the name of state surveillance. Both sides have to moderate their approach. The golden coin owner must tolerate the Public Authorities doing their duty.

\section{References}

Antoniadis, I., Sariannidis, N., \& Kontsas, S. (2018) The Effect of Bitcoin Prices on US 


\section{Macrothink}

Business and Economic Research ISSN 2162-4860 2020, Vol. 10, No. 1

Dollar Index Price. In: N. Tsounis \& A. Vlachvei (Eds.), Advances in Time Series Data Methods in Applied Economic Research. ICOAE 2018. Springer Proceedings in Business and Economics. Springer, Cham. https://doi.org/10.1007/978-3-030-02194-8_34

Athanasios, Z. (2016). General Purpose Recording Device To Embed Forensics Accepted Digital Certificates To The Internet Distributed Art. Communication And Politics Multimedia Products, EU patent, 20160100277, Athens.

Baur, D. G., Dimpfl, T., \& Kuck, K. (2018). Bitcoin, gold and the US dollar-A replication and extension. Finance Research Letters, 25, 103-110.

https://doi.org/10.1016/j.frl.2017.10.012

Berger, T., \& Frey, C. B. (2016). Structural Transformation in the OECD. https://doi.org/10.1787/1815199X

Biryukov, A., \& Tikhomirov, S. (2019). Security and privacy of mobile wallet users in Bitcoin, Dash, Monero, and Zcash. Pervasive and Mobile Computing, 101030. https://doi.org/10.1016/j.pmcj.2019.101030

Bordo, M. D., \& Levin, A. T. (2017). Central bank digital currency and the future of monetary policy (No. w23711). National Bureau of Economic Research.

https://dx.doi.org/10.3386/w23711

Bui, T., Rao, S. P., Antikainen, M., \& Aura, T. (2019, March). Pitfalls of open architecture: How friends can exploit your cryptocurrency wallet. In Proceedings of the 12th European Workshop on Systems Security (p. 3). ACM. https://doi.org/10.1145/3301417.3312495

Campbell, G., Crystal, D., \& Siegfried, B. R. (2011). Bible: The Story of the King James Version, 1611-2011; Begat: The Story of the King James Bible and the English Language. BYU Studies Quarterly, 50(3), 10. [Online] Available:

https://scholarsarchive.byu.edu/byusq/vol50/iss3/10

Carlstrom, C. T., \& Fuerst, T. S. (2007). Asset prices, nominal rigidities, and monetary policy. Review of Economic Dynamics, 10(2), 256-275. https://doi.org/10.1016/j.red.2006.11.005

Catalini, C., \& Gans, J. S. (2018). Initial coin offerings and the value of crypto tokens (No. w24418). National Bureau of Economic Research. https://DOI.org/10.3386/w24418

Clarke, D. J. (2016). A Theory of Rational Demand for Index Insurance. American Economic Journal: Microeconomics, 8(1), 283-306. https://doi.org/10.1257/mic.20140103

Eckel, C. C., \& Ragan, P. (2011). Face Value. American Economic Review, 101(4), 1497-1513. https://doi.org/10.1257/aer.101.4.1497

Eken, M. H., \& Baloglu, E. (2018). Crypto Currencies and Their Destinies in the Future. International Journal of Finance \& Banking Studies, 6(4).

https://doi.org/10.20525/ijfbs.v6i3.810

Fung, B. S., \& Halaburda, H. (2016). Central bank digital currencies: a framework for assessing why and how. http://dx.doi.org/10.2139/ssrn.2994052 


\section{Macrothink}

Business and Economic Research ISSN 2162-4860 2020, Vol. 10, No. 1

Gerakis, G., Razis, D., \& Zisopoulos, A. (2016). NICODIMUS, a forensic device to support Avocate and Judger public function and office. International Symposium on Ambient Intelligence and Embedded Systems, AmiEs 2016, Heraklion, Crete, Greece.

Goel, A. (2015). Gold Monetisation Scheme. Global Journal of Multidisciplinary Studies, 4(8). [Online] Available: https://ssrn.com/abstract=2707138

Grierson, P. (1973). Catalogue of the Byzantine Coins in the Dumbarton Oaks Collection and in the Whittemore Collection: Leo III to Nicephorus III, 717-1801 (Vol. 3). Dumbarton Oaks.

Healy, J. F. (1980). Greek white gold and electrum coin series. Metallurgy in numismatics, 1, 194-215.

Heathcote, N. H. (1967). The early meaning of electricity: Some Pseudodoxia Epidemica-I. Annals of Science, 23(4), 261-275. https://doi.org/10.1080/00033796700203316

Hennig, J. E., Ladkin, P. B., \& Sieker, B. (2004). Privacy enhancing technology concepts for RFID technology scrutinised. RVS Group, Bieldefeld.

Hidetaka, K. (2010). What Did Archimedes Find at "Eureka" Moment?. In The Genius of Archimedes-23 Centuries of Influence on Mathematics, Science and Engineering (pp. 265-276). Springer, Dordrecht. https://doi.org/10.1007/978-90-481-9091-1_18

Howgego, C. (2002). Ancient history from coins. Routledge.

https://doi.org/10.4324/9780203135860

Jokić, S., Cvetković, A. S., Adamović, S., Ristić, N., \& Spalević, P. (2019). Comparative analysis of cryptocurrency wallets vs traditional wallets. Ekonomika, 65(3), 65-75.

https://doi.org/10.5937/ekonomika1903065J

Julien, B., David, C., Alcino, C., \& Nuno, M. (2018). The Electrum Analyzer: Model Checking Relational First-Order Temporal Specifications. 33rd ACM/IEEE International Conference on Automated Software 2018, Montpellier, France.

http://10.1145/3238147.3240475.hal-01846951v2

Kolata, G. (2003). In Archimedes' puzzle, a new eureka moment. New York Times, 153(52, 697), 1.

Kumhof, M., \& Noone, C. (2018), Central Bank Digital Currencies - Design Principles and Balance Sheet Implications May 18, 2018. Bank of England Working Paper No. 725. http://dx.doi.org/10.2139/ssrn.3180713

Langschaedel, J., Armstrong, B. D., \& Ehrsam, F. E. (2015). U.S. Patent Application No. 14/660, 331. [Online] Available: https://patents.justia.com/inventor/julian-langschaedel

Lashitew, A. A., Tulder, R., \& Liasse, Y. (2019). Mobile phones for financial inclusion: What explains the diffusion of mobile money innovations?. Research Policy, 48(5), 1201-1215. https://doi.org/10.1016/j.respol.2018.12.010

Lyrintzis, C., Nikolakopoulos, H., \& Sotiropoulos, D. (1996). Society and politics: aspects of 
the Third Hellenic Republic, 1974-1994. Themelio, Athens.

Macfarquhar, C. C. et al. (2016). Encyclopaedia Britannica, Or, a Dictionary of Arts, Sciences, and Miscellaneous Literature: Constructed on a Plan, by Which the Different Sciences and Arts Are Digested Into the Form of Distinct Treatises Or Systems, Comprehending the History, Theory, Creative Media Partners, LLC.

Mayers, D., \& Smith, Jr, C. W. (1983). The interdependence of individual portfolio decisions and the demand for insurance. Journal of Political Economy, 91(2), 304-311.

https://doi.org/10.1086/261145

Naylor, R. T. (2003). 11 Follow-the-Money Methods in Crime Control Policy. Critical reflections on transnational organized crime, money laundering and corruption, 256.

https://doi.org/10.3138/9781442670242-013

Pászthory, E. (1980). Investigations of the early electrum coins of the Alyattes type. Metallurgy in numismatics, 1, 151-156.

Renneboog, L., Ter Horst, J., \& Zhang, C. (2011). Is ethical money financially smart? Nonfinancial attributes and money flows of socially responsible investment funds. Journal of Financial Intermediation, 20(4), 562-588. https://doi.org/10.1016/j.jfi.2010.12.003

Schlesinger, H. (2013). The theory of insurance demand. In Handbook of insurance (pp. 167-184). Springer, New York, NY. https://doi.org/10.2307/253910

Schwarz, P. (2011). Money launderers and tax havens: Two sides of the same coin?. International Review of Law and Economics, 31(1), 37-47.

https://doi.org/10.1016/j.irle.2010.12.001

Sharman, J. C., \& Mistry, P. S. (2008). Considering the consequences: The development implications of initiatives on taxation, anti-money laundering and combating the financing of terrorism. Commonwealth Secretariat. https://doi.org/10.1057/jbr.2008.26

SINGER, Graciela GESTOSO. (2008). Amber in the Ancient Near East.

Singh, K., \& Best, P. (2019). Anti-Money Laundering: Using data visualization to identify suspicious activity. International Journal of Accounting Information Systems, 34, 100418. https://doi.org/10.1016/j.accinf.2019.06.001

Spiekermann, S., \& Evdokimov, S. (2009). Privacy enhancing technologies for RFID-a critical state-of-the-art report. IEEE Security and Privacy, 7(2), 56-62.

https://doi.org/10.1109/MSP.2009.31

Stein, S. (1999). Archimedes: what did he do beside cry eureka? (Vol. 11). MAA.

Teichmann, F. (2017). Twelve methods of money laundering. Journal of Money Laundering Control, 20(2), 130-137. https://doi.org/10.1108/JMLC-05-2016-0018

Thomas, L-P. T. (2010). Money, the meaning of money, management, spirituality, and religion. Journal of Management, Spirituality \& Religion, 7(2), 173-189. 
https://doi.org/10.1080/14766081003746448

Titus, K. (2005). Inventor. Debt Elimination Business Method. United States patent application US 10/905,593. [Online] Available: https://patents.google.com/patent/US20050086162A1/en

Tucker, W., Codry, S., \& Halperin, J. L. (2008). Heritage World Coin Auction\# 3000 Long Beach. Heritage Capital Corporation.

Usman, K. M. (2014). Anti-money laundering regulations and its effectiveness. Journal of Money Laundering Control, 17(4), 416-427. https://doi.org/10.1108/JMLC-06-2013-0022

Vasilios, K., Athanasios, Z., \& Konstantinos, S. (2018). Law, Ethics and tech aspects for an Irrevocable BlockChain based Curriculum Vitae created by Big Data analytics fed by Internet of Things, sensors and all type of approved data sources. International Journal of Management Innovation Systems, 3(1). https://doi.org/10.5296/ijmis.v3i1.13774

Vasilios, K., Athanasios, Z., \& Papangelou, S. (2018). Small Forensic "Smart-Law-Scripts" the First Step for Intelligent Justice Punishment in Law Enforcement, Economic Crime and Alternative Sentences. Business and Economic Research, 8(2), 154-167.

https://doi.org/10.5296/ber.v8i2.13045

Venegas, Percy, Initial Coin Offering (ICO) Risk, Value and Cost in Blockchain Trustless Crypto Markets (August 1, 2017). http://dx.doi.org/10.2139/ssrn.3012238

Volety, T., Saini, S., McGhin, T., Liu, C. Z., \& Choo, K. K. R. (2019). Cracking Bitcoin wallets: I want what you have in the wallets. Future Generation Computer Systems, 91, 136-143. https://doi.org/10.1016/j.future.2018.08.029

Wallace, R. (1989). On the production and exchange of early Anatolian electrum coinages. Revue des études anciennes, 91(1), 87-94. https://doi.org/10.3406/rea.1989.4367

Whiting, D. P. (1994). Money. In Mastering Banking (pp. 1-18). Palgrave, London. https://doi.org/10.1007/978-1-349-13240-9_1

\section{Copyright Disclaimer}

Copyright for this article is retained by the author(s), with first publication rights granted to the journal.

This is an open-access article distributed under the terms and conditions of the Creative Commons Attribution license (http://creativecommons.org/licenses/by/3.0/). 